\title{
Implementation of Pantawid Pamilyang Pilipino Program (4ps) in Barangay Talumpok, Batangas City
}

Aguado, Anabelle $\measuredangle$

Talumpok Integrated School, Philippines (anabelle.aguado@deped.gov.ph)

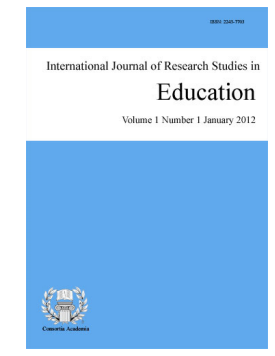

Accepted: 30 May 2021

ISSN: 2243-7703 Online ISSN: 2243-7711

OPEN ACCESS

\section{Abstract}

In the Philippines, it cannot be denied that its citizens are under the circumstance of poverty. Pantawid Pamilyang Pilipino Program (4Ps) is one of the fully operational assistance currently implemented by the Department of Social Welfare and Development (DSWD) and supported by the other government agencies. Descriptive survey method was used to gather pertinent facts and data on the parents of 91 beneficiaries of Pantawid Pamilyang Pilipino Program currently enrolled at Talumpok Integrated School. Questionnaire was the main instrument used in gathering data and supplemented by interview with the use of interview guide. The statistical tools applied to interpret the gathered data were Frequency, Percent and Rank to find out the level of frequency of the items in the demographic profile of the respondents. The study found that beneficiaries met the requirements set by the program and qualified to become. In terms of the support of 4P's to its beneficiaries on parenting and home management, health and nutrition and education, it is assessed as highly provided and viewed as parallel and accordance with the goal of 4Ps. As to extent of implementation, parenting and home management, health and nutrition and education are in great extent. This emphasizes that 4Ps in terms of social welfare and development to the beneficiaries is effective. Correlation shows a highly significant relationship of 4Ps support and the level of implementation on social welfare and development. On the other hand, there are problems identified by 4Ps beneficiaries which focus merely on the cash grants discrepancies and delay transactions. The root cause of the problems why beneficiaries are still amid dependency to the program is not yet addressed. Meanwhile, proposed enhancement 4Ps project was presented as guide for beneficiaries and 4Ps to strengthen its implementation which requires maximum involvement of school personnel, parents, and 4Ps community officials.

Keywords: beneficiaries; Department of Social Welfare and Development; family; Pantawid Pamilyang Pilipino Program; poverty 


\section{Implementation of Pantawid Pamilyang Pilipino Program (4ps) in Barangay Talumpok, Batangas City}

\section{Introduction}

Since the beginning of time, life seemed to man as a constant daily battle which needs fulfilment or satisfaction. For many, every day is a joust against factors that hinder them to reach full potential or self-actualization. One of these factors that have challenged a myriad of past and present generations is poverty. As defined by Crossman (2017), poverty is a social condition characterized by the lack of resources necessary for basic survival or necessary to meet a certain minimum level of living standards expected for the place where one lives. This definition is supported by the Asian Development Bank (2013) which revealed that the causes of poverty are low employment opportunities, substandard to moderate economic growth for several decades, income inequality, and external shocks such as natural calamities, economic crises, and political issues.

It is an unfortunate and saddening truth that poverty is a huge, prevalent challenge affecting billions of lives across the globe. In the recent data, 7.53 billion citizens of the world, 736 million people live in extreme poverty, making ends meet on less than $\$ 1.90$ a day. Four hundred thirteen million people or more than half of the world's extreme poor reside in sub-Saharan Africa. The international poverty line is currently set at $\$ 1.90$ which tells that it is the amount of money necessary to live a decent life (World Vision, 2018).

People who fall under the multidimensional poverty line are being left behind across the following key dimensions: health, education, and standard of living. Under health, it can be classified as deprived if in a household there is an adult under 70 years of age or a child who is undernourished and, if there is any child who has died in the family in the five-year period preceding the survey. With education, the indicators are as follows: no household member aged 10 years or older has completed six years of schooling and any school-aged child is not attending school up to the age at which he/she would complete class 8 (United Nations Development Program, 2020).

In the Philippines, it cannot be denied that their citizens are under the circumstance of poverty. Most of the time, making a living for their families and especially for their children is really a hard task. Since basic needs, especially food are impossible for many, it can be deemed that education is an even harder privilege to have. Even though the country recognizes the importance of education in promoting progress and development, still, poverty left no space for education, it consumed everything. Data gathered by the National Statistical Coordination Board (2014) show that more than one-quarter of the population fell below the poverty line in the first semester of 2014, an approximate 78 percent increase since 2013. Poverty as a social problem brought great impact on the lives of the people especially on families who are exposed to this situation.

Through the government's initiative, there are programs set in the past administration which addressed poverty. Social Reform Agenda (SRA) by the Ramos Administration organized 10 flagship projects in agricultural development, housing, integrated delivery of social services and institution-building. Another one is the Lingap Para sa Mahihirap (Caring for the Poor) Program by Estrada Administration in 1998 which focused on medical assistance, livelihood, housing, and protective services to the poorest families. Kapit-Bisig Laban sa Kahirapan (KALAHI) in 2001 by the Arroyo Administration launched the poverty reduction and integrated convergence strategy to improve delivery of services for the poorest municipalities and provinces in the country. Unfortunately, all these programs were dropped after the administration.

Nowadays, Pantawid Pamilyang Pilipino Program (4Ps) is one of the assistance projects which are fully operational and currently implemented by the Department of Social Welfare and Development (DSWD) and supported by other government agencies such as Department of Health (DOH), Department of Education 
(DepEd), local government officials (LGUs) and civil society organizations (CSO) with the goal of providing and improving quality of life among the beneficiaries.

Following compliance to certain health and education conditions, each beneficiary family receives a health grant of five hundred pesos (P500) per month or a total of six thousand pesos (P6, 000.00) per year. Each beneficiary family also receives an education grant of three hundred pesos (P300.00) per month for the ten (10) month school year or a total of three thousand pesos $(\mathrm{P} 3,000.00)$ in a year, with a maximum of three (3) children per household (DSWD, 2009).

Meanwhile, some of the conditions set by the program include the following: parents must ensure that their children attend school at least $85 \%$ of the time and receive vaccinations and health care; pregnant women must receive pre- and post-natal care and be attended during childbirth by a skilled health professional and parents' participation in Family Development Sessions (FDS) to interact with other beneficiaries could strengthen the social and community engagement of 4Ps recipients. Among the topics discussed during FDS are parenting and home management, health and nutrition, and education (4Ps Official Gazette of the Republic of the Philippines).

Likewise, beneficiaries of this program are expected to use the assistance especially for educational and health purposes. It aims to eradicate extreme poverty in the Philippines by investing in health and education particularly for children from 0-18 years of age. As of 2019, this program operates in 17 regions, 79 provinces and 143 cities, and 1,484 municipalities covering 4,326,208 household beneficiaries (4Ps Official Gazette of the Republic of the Philippines).

Talumpok, Batangas City is the locale of the study with 117 4Ps beneficiaries. It is characterized as a rural community on the foot of Mt. Banoy wherein farming and livestock are commonly engaged activities among its residents. Due to economic activities of the beneficiaries, it is not enough to suffice the needs of the family since cash grants received by 4Ps beneficiaries for health and education are used for basic needs. Thus, recipients are unable to comply with the conditions set by the program specifically on health and education. Children choose over school just to help parents meet the basic needs. Such decisions result in non-compliance to 4Ps conditions due to consecutive absences.

\subsection{Statement of the problem}

The study aimed to determine the extent of implementation of Pantawid Pamilyang Pilipino Program (4Ps) on the social welfare and development of its beneficiaries in Barangay Talumpok, Batangas City. It sought to answer the demographic profile of 4Ps beneficiary families in terms of household size, number of beneficiary children, educational attainment, dwelling characteristics, assets, and source(s) of income. Additionally, it sought to find the support being provided by 4Ps to its beneficiaries and the extent of its implementation in terms of parenting and home management, health and nutrition, and education. Meanwhile, the study also sought to find the relationship of 4Ps support and the level of implementation in terms of parenting and home management, health and nutrition and education. This study also intended to seek the common problems experienced by the members and beneficiaries of 4Ps. And lastly, based on the analysis, a project was proposed to strengthen the implementation of 4Ps among the beneficiaries.

\section{Methodology}

\subsection{Research design}

The research used a descriptive method to gather pertinent facts and data regarding the overall logical presentation of the study. It involved description, analysis and interpretation of conditions that now exist. Often includes the comparison and contrast and attempts to discover the cause-and-effect relationship that exists in the study. With the aid of statistical treatment of data, appropriate conclusions on findings and recommendations 
Aguado, A.

were generated to support the analysis. In the study, it aimed to determine the support given by Pantawid Pamilyang Pilipino Program and the extent of its implementation among the beneficiaries. Meanwhile, it also intended to determine the relationship of 4Ps support and the level of implementation on the aspects of parenting and home management, health and nutrition and education.

\subsection{Participants}

The subjects of the study were parents of the 91 beneficiaries of Pantawid Pamilyang Pilipino Program currently enrolled at Talumpok Integrated School. The parents were 24 from grade 7 students; 26 from grades 8 ; 20 from grade 9 and 21 from grade 10 students. The sample population was 91 out of 117 which resulted from Slovin's formula at 5 percent margin error to determine the sample frame.

\subsection{Data gathering instrument}

Survey-questionnaire was the instrument used for data gathering. It was divided into three parts: Part I is the demographic profile of the respondents such as age, sex, household size, number of beneficiary children, educational attainment (father's education and mother's education), dwelling characteristics, assets and ownership and source(s) of income, Part II focused on the Support Provided by 4P's to its Beneficiaries in terms of parenting and home management, health and nutrition, and education and Part III is the extent of application of 4P's on Social Welfare and Development of its Beneficiaries in terms also of parenting and home management, health and nutrition, and education. The items and variables used in this study were carefully studied and verified for appropriateness of responses.

For the questionnaire to be valid for the study, the researcher consulted the adviser and statistician for critiquing and validating the questionnaire. Furthermore, the researcher also sought the assistance of the Department of Social Welfare and Development (DSWD) for the validation of the instrument as they are the agency that manages the Pantawid Pamilyang Pilipino Program (4Ps) in the country. Moreover, since 4Ps is part of the national program of the government, protocols should be strictly followed. Upon completion of the necessary documents, an endorsement letter was formally forwarded to the researcher as evident that the instrument to be used in the study was already validated and approved by the DSWD Regional Office. The researcher also used interviews as an effective way in gathering primary data qualitatively. To have more reliable data, the researchers used a semi-structured form of interview (Cohen \& Crabtree, 2006). The respondents used in the interview were 21 parents of students' beneficiaries of Talumpok Integrated School.

\subsection{Data gathering procedure}

The researcher sought the assistance of a statistician and the DSWD Regional Office in validating the questionnaire. Through the coordination with the City Welfare Development Office (CSWDO) administering the questionnaires took place. Two sessions of administration of instruments were done. First was held at Barangay Hall of Talumpok West, Batangas City. It was personally administered by the researcher through the assistance of the 4P's coordinator of the CSWDO after the scheduled Family Development Session (FDS) wherein varied issues and concerns such as parenting and home management, nutrition health and nutrition and education were discussed. It was done at Talumpok National High School Gymnasium for those 4P's beneficiaries who were in school for Brigada Eskwela and who have attended their FDS in Talumpok Silangan, Batangas City. It was also administered by the researcher personally to ensure $100 \%$ return. A consent form for interviews was also attached to the instrument as an agreement for the respondents to be used as the subject of the study. All responses to the items were scored and entered in a master data sheet. The data gathered were also consolidated in tables using the statistical methods. Items were finally analyzed as shown in the results of the assessment in each table.

16 Consortia Academia Publishing (A partner of Network of Professional Researchers and Educators) 


\subsection{Statistical treatment of the data}

All the responses to all the items in the questionnaire were scored and entered in a master data sheet to ensure accuracy and correctness of results. Entries were carefully rechecked for analysis. To arrive at the relevant answers, including the specific objectives of the study, the data were gathered and treated statistically using tools such as frequency, Percent and Rank, weighted mean and Regression and Correlation Analysis. Data were interpreted guided by the literature gathered. The study used Frequency, Percent and Rank to find out the level of frequency of the items in the demographic profile of the respondents. Weighted Mean was also used to determine and assess the support of 4P's to its beneficiaries as well as the level of implementation of 4P's on social welfare and development of the beneficiaries on health and nutrition, education, housing, and economic sufficiency. The scales used in the support provided by 4Ps are 4-highly provided, 3-moderately provided, 2- less provided and 1-least provided while for the extent of implication, 4-very great extent, 3-great extent, 2-less extent, and 1-least extent. And to describe and interpret the data objectively, the Four-Point Likert Scale was used. The study used correlation analysis, particularly, the Pearson Product Moment of Correlation to assess the relationship of 4Ps support and the level of implementation on social welfare and development to its beneficiaries.

\section{Result and discussion}

\subsection{Demographic profile of 4Ps beneficiary families}

Based on household size, the biggest number of respondents was on the range of three to five and only six for more than 10, on the number of beneficiary children of 4Ps families have two to three dependency ratios of 4Ps beneficiaries which suggest that most of the family beneficiaries are with maximum number of children who can benefit from the program as cited in its program benefits, as to educational attainment, majority of the parents of the family-beneficiaries were high school graduates while majority of them were not high school graduates. Meanwhile, based on the dwelling characteristics of 4Ps' family beneficiaries, the roofing was made of iron sheet while when it came to their walls, they were made of light materials. On the other hand, when it comes to the toilet system, the majority of the beneficiaries were using the pail system. As to the assets, the socio-economic status of the family with regards to home ownership showed that family cited own the house they are residing and for the gadgets/appliances owned, majority of the family beneficiaries own a cell phone. As regard to vehicle ownership, respondents divulged that they do not own any vehicle. More so, for the sources of income, 4Ps families are more engaged in agriculture-related activities. The proportion of working members in 4Ps families whose sector of employment falls under agriculture/fishery/forestry is more than twice that in non-4Ps families. On the other hand, when it comes to craft and related trade workers, most of the respondents were sewer as their source of income, while as to plant and machine operators and assemblers a total of 15 respondents have divulged that they were plant and machine operators and assemblers for their source of income. As to service and sales workers as source of income, the majority from this group or respondents were drivers as shown by the biggest gathered response of 15 or 16.48 and another 15 or 16.48 percent who did not divulge their source of income.

\subsection{Support being provided by 4 Ps to its beneficiaries}

In terms of parenting and home management, activities for parenting and home management are provided by the government in response to the implementation of the 4Ps. This was further evidenced by the highest weighted mean of 3.70 , on the activities that focused on building family values. When it comes to health and nutrition, respondents revealed that the government's 4Ps highly provide free immunization to 0 to 5 years old children in coordination with the DOH and LGU. Meanwhile, in terms of education, respondents have cited that generally, the government's 4Ps have highly provided avenues for family-beneficiaries to evolve from being poor to sustaining families. This is shown in the composite mean of 3.64. 
Aguado, A.

\subsection{Extent of implementation of 4Ps on social welfare and development of its beneficiaries}

Results show that parenting and home management programs are observed as evidenced by the highest weighted mean of 3.62 on that ability of parents and/or guardians to discern problems in family and arrive at solutions were enhanced. It can be said that 4Ps support in its beneficiaries' health and nutrition were highly observed as shown by its composite mean of 3.44. As to education, 4Ps is effective to a very great extent as shown by the composite mean of 3.60. The program's effectiveness is of very great extent as shown by the increased school enrolment, given with the highest weighted mean of 3.70. For the extent of application of 4Ps on social welfare and development, beneficiaries were to a very great extent as revealed by the composite mean of 3.56 .

\subsection{Relationship of 4Ps support and the level of implementation on social welfare and development to its beneficiaries}

As can be seen, there is a highly significant relationship between the relationship of 4ps support and the level of application on social welfare and development to its beneficiaries.

\subsection{Common problems experienced by the members and beneficiaries of $4 P s$}

Based on the interviews, problems cited by the 4Ps beneficiaries were discrepancies in the cash grants they received. Due to non-compliance, cash granted was automatically deducted or cut off. Another problem was delay of cash grants transactions/pay-out which resulted in pending payment of their borrowed cash or neglected payment. Spending cash grants to basic needs instead on health and education was also a problem. Meanwhile, some beneficiaries cited that in their FDS, livelihood training must be conducted for them to be able to have ideas on how to have additional income to meet other aspects of their survival.

\subsection{Proposed project for 4 Ps and beneficiaries}

This study proposed a project for the 4Ps and beneficiaries which requires maximum involvement of school personnel, parents, 4Ps beneficiaries and barangay officials. The developed project aimed to enhance the implementation of the program to qualified beneficiaries.

\section{Conclusions}

Based on the results of the study, the beneficiaries met the requirements set by the program and thus, they are qualified to become beneficiaries, the 4Ps support given to the beneficiaries is parallel and in accordance with the goal of 4Ps and as to extent of implementation, parenting and home management, health and nutrition and education is in great extent. This emphasizes that 4Ps in terms of social welfare and development to the beneficiaries is effective. Meanwhile, a highly significant relationship of 4Ps support and the level of implementation on social welfare and development is recorded. On the other hand, problems by 4Ps beneficiaries focus merely on the cash grants discrepancies and delay transactions. The root cause of the problems why beneficiaries are still amid dependency to the program is not yet addressed. Lastly, proposed enhancement of 4Ps project and beneficiaries requires maximum involvement of school personnel, parents, and 4Ps/community officials.

\subsection{Recommendations}

Based on the findings and conclusions, the study recommends that the proposed project can be subjected for further review for enhancement prior to implementation, trainings/seminars in different income-generating programs may be conducted to equip community people the needed skills and technology to enable them to establish their own business, the government must deepen their understanding about the real scenario of the poor

18 Consortia Academia Publishing (A partner of Network of Professional Researchers and Educators) 
since, root cause of beneficiaries' dependency must be addressed first and lastly, similar studies may be conducted to determine the effectiveness of the program.

\section{References}

Abelos, A. V. (2006). Sociology with introduction to anthropology in a global perspective: A comprehensive textbook in sociology and basic anthropology a guidebook in society and culture. Manila, Philippines: Educational Publishing House.

Alday, M. (2011). The community extension service program for University of Batangas [Unpublished doctoral dissertation]. University of Batangas, Batangas City, Philippines.

Anas, R. G., \& Anas, D. G. (2016). The implementation of 4ps and the scholastic achievements of the secondary school students-recipients in Oton Iloilo. Ijaber, 14(5). Retrieved from https://www.serialsjournals.com/index.php?route=product/product/volumearticle\&issue id=293\&produ ct_id=343

Asian Development Bank. (2013). Poverty reduction: Promoting inclusive pro-poor growth. Retrieved from http://www.adb.org/themes/poverty/overview

Banaag, Y. (2007). School involvement in community development: Bases for enhanced participation [Unpublished doctoral dissertation]. University of Batangas, Batangas City, Philippines.

Bastagli, F. (2009). From social safety net to social policy? The role of conditional cash transfers in welfare state development in Latin America [Working Paper No. 60]. The International Policy Centre for Inclusive Growth (IPC-IG), Brasilia, Brazil. Retrieved from http://www.undp-povertycentre.org/Home.do?active=0

Brilliantes, A. B., Mangahas, J. V., Mariano, V. D., \& Alcid, R. (2007). Making services work for the people: Leading practices in improving service delivery at the national government level. Manila: University of the Philippines.

Bustos, A. S., \& Espiritu, S. C. (1985). Psychological, anthropological and sociological foundations of education. Manila: Katha Publishing.

Calvo, C. (2011). Social work and conditional cash transfers in Latin America. The Journal of Sociology \& Welfare, 38(3), 53-72.

Chaudhury, N., \& Okamura, Y. (2012). Conditional cash transfers and school enrollment: impact of the conditional cash transfer program in the Philippines. Policy Research Working Paper Series. The World Bank Group.

Coady, D. P., \& Parker, S. W. (2002). A cost-effective analysis and demand and supply-side education interventions: The case of progresa in Mexico. IFPRI, 8(3), 440-451. https://doi.org/10.1111/j.1467-9361.2004.00244.x

Crossman, A. (2017). Understanding poverty and its various types. Retrieved from https://www.thoughtco.com/poverty-3026458

De Guzman, E. (2015). Academic achievement of pantawid pamilyang pilipino program (4Ps) beneficiaries in public secondary schools in Laguna [Unpublished doctoral dissertation] Polytechnic University of the Philippines, Manila, Philippines.

del Castillo, F. A., del Castillo, C. D. B., \& Corpuz, J. C. (2021). COVID-19 and the well-being of the homeless population. Disaster Medicine and Public Health Preparedness. https://doi.org/10.1017/dmp.2021.45

Garcia, M. B. (1994). Social problems in the Philippine context. Manila: National Bookstore.

Lazo, R. S. (2006). Philippine governance and the 1987 constitution. Manila: Rex Book Store.

Mohanty, S. R. (2016). Introduction to home management. Hamburg: Anchor Academic Publishing.

Orbeta, A., \& Pacqueo, V. (2013). Does pantawid poster dependence or encourage work? [Unpublished masteral thesis]. Philippine Institute for Developmental Studies, Makati City, Philippines.

Tudor, M. (2014). The impact of Philippines' conditional cash transfer program on consumption [Unpublished masteral thesis]. University of the Philippines School of Economics, Diliman, Quezon, Philippines

United Nations Development Program. (2020). The 2020 global multidimensional poverty index (MPI). 
Aguado, A.

Retrieved from http://hdr.undp.org/en/2020-MPI

World Vision. (2018). Global poverty: Facts, FAQs, and how to help. Retrieved from https://www.worldvision.org/sponsorship-news-stories/global-poverty-facts 